\title{
THE STRUGGLE AGAINST GLOBAL TERRORISM AS AN EXPRESSION OF A CLASH BETWEEN CIVILISATIONS
}

World War III is a war between civilizations that has been occurring for some time. The main characteristic of World War III, which is underway, is the war against radical terrorism; that is attempting to change the world order and to sow fear among both citizens and governments in the free world in general, and in Europe in particular.

Samuel Huntingdon maintains in his article "The Clash of Civilizations" that the great disputes in the human species and the main sources of conflicts were cultural. In addition he held that the nation state will remain the main players in the global arena, but the essential conflicts in global politics will occur between nations and groups that belong to different civilizations (Huntingdon, 1993: 26). Huntingdon took the expression "clash between civilizations" from the Jewish Orientalist, Professor Bernard Lewis (1990: 49). This is the situation, beginning from the 1960s.

Huntingdon further maintained that people can redefine their identity and consequently change the borders and compositions of civilizations. When looking at the phenomenon of the 'Islamic State', it is apparent that this is indeed the case.

For the main question of why the civilizations will clash, Huntingdon (1993: 31) responds that the great clashes will occur on the cultural fault lines that separate between these civilizations. It is possible to see the difference between Western culture and radical jihadist Islamic culture, which is represented by the Islamic State.

The clash between civilizations occurs on two levels, the micro level and the macro level. The micro level is the territorial struggle between neighboring groups along the fault lines between the civilizations, such as the spread of the Islamic State organization. The macro level is that states belonging to different civilizations compete for military and economic power, and for control over international institutions and other countries, while promoting their political and religious values. Iran can constitute a significant example of this argument (Huntingdon, 1993: 31).

It is possible to discern with relative ease the cultural difference between civilizations that support terrorism, and Western civilizations. Western civilizations are characterized by a cultural infrastructure that holds sacred individual liberties, pluralism, and democracy; While the civilizations that engage in radical terrorism express their belief through the dissemination of terror and fear. For example, the Islamic State organization disseminates many video clips filmed by its warriors before or after the conquest of many sites. They: behead people, conduct mass slaughter by firing into pits, drown captives in cages, burn people alive, amputate hands and feet, stone people 
to death, throw LGBT people from rooftops, use children to commit brutal acts of murder, and so on (Perlov, 2015: 94).

At the end of the 1960s, the problem of international terrorism was not addressed with the same degree of importance as it is today, and therefore it was not properly understood. Few focused on the nature of the factors that were responsible for the worrisome spread of terrorism. Few believed that there were practical ways to fight terrorists, and even to defeat them.

The Western world, since three decades after the end of World War II, has been under the steadily increasing attack of international terrorism. These attacks ranged from: the hijacking of a TWA airplane to Beirut, the hijacking of the Achilles Lauro ship, the planned explosion on a passenger airplane that flew from Rome to Athens. The attacks reached a climax with the combined terrorist attacks on the United States on September 11, 2001. Terrorists from Al-Qaeda hijacked airplanes and crashed them into settled regions, with emphasis on the Twin Towers in New York, an event that some maintain constituted the watershed moment. In addition, the terrorist attacks in recent years in Europe and the threat reflected by the Islamic State Organization and other murderous organizations, only strengthened the fear of the waves of acts of violence and harm to the innocent. All these events clarified to the world that a terrible world war is being waged and is spreading. This situation is supposed to cause the leaders of the free world to initiate activity and offer proposals regarding the ways that may lead to effective struggle against the increasing threat.

The countries of the West, which are the primary target of international terrorism, must head into battle without compromise against those who threaten the freedom and texture of life that was reconstructed after World War II with the work of many years. They must and can adopt for themselves a series of political, economic, military, and legal measures so as to wage war against the murderous terrorist organizations and their followers.

The following question is therefore asked; Why do the terrorists and their supporters choose the countries of the West and other countries as easy targets of terrorism? From an ideological perspective, the world of values of the free societies is found in complete contradiction with the values of terrorism (Netanyahu, 1996: 19). In democratic regimes, the government derives its authority from the consent of the citizens. Even then the power is limited by the painstaking maintenance of the person's fundamental freedoms. In these societies conflicts between different groups are resolved through political means, which by nature are non-violent. The terrorist organization does not recognize these qualifications. The terrorists and their supporters believe that the Western countries are soft and easy targets. They exploit the great openness of the free societies, to plan and perform different attacks. They rely on the assumption that the humaneness of the Western countries, and the limitations that the rule of law imposes on them, will prevent them from responding aggressively to their deeds (Schultz, in Netanyahu, 1997: 82).

Terrorism generally flourishes when there is an atmosphere of weakness and lack of agreement, regarding the manner of treatment of the case of a terrorist attack or another violent activity on its part. It should be noted that in a short period of time of about twenty years terrorism has become a global power. Terrorism strikes methodi- 
cally, almost without exception, at most of the democratic countries. Terrorism threatens international traffic routes, international trade, and international treaties. When focusing on the nature of international terrorism, it is first necessary to acknowledge the fact that this type of terrorism did not grow and develop only from social feelings of distress and frustration. International terrorism derives primarily from the cultural political aspirations of countries that want to expand, and that support terrorism and terrorist organizations. These countries set for themselves the goal of using the weapon of terrorism, through the support of terrorist organizations and other radical organizations at their disposal. Without the support of these countries, international terrorism would not exist and spread. One of the destructive influences of terrorism is the very blurring of the distinctions between combatants and civilians, a distinction that is at the root of the rules of war (Harkavi, 1983: 59). This point separates the terrorist from the other fighters, since he declares total war on society and even challenges its institutions. In his eyes, every person is a legitimate target. The harm to women, children, and babies does not constitute any barrier for them.

World War III is the war against terrorism. The threat and harm to countries in Europe and in the United States crosses continents and borders, and does not stop at any way to realize the aggression against those who do not toe the line with their ideas and aspirations.

The terrorist attacks in the United States, in Europe, and in other places in the world; prove that the causes of terrorism have no barrier regarding the degree of harm, and any person who is not a part of the radical ideology is doomed to destruction and/or surrender.

\section{EUROPE AND THE SO-CALLED ISLAMIC STATE: CASE STUDY. PHENOMENON OF THE ISLAMIC STATE}

The main goal of the Islamic State organization is to establish a caliphate for all Muslims. The organization of the Islamic State broke off from the Al Qaeda organization in Iraq, at first became the Islamic State in Iraq and Syria (Daesh). Later, it called itself the Islamic State while taking over areas in Iraq and Syria and even beyond, such as Sinai in Egypt and Libya.

The organization of the Islamic State has the goal of creating territorial continuity and implementing Sunni Salafi law from the period of the Prophet Mohammed on the entire population; including Sunnis, Shiites, Christians, Jews, and members of other religions. The mode of action of the Islamic State organization was expressed in that it is necessary to completely erase the Western influences of the end of the $19^{\text {th }}$ century and the $20^{\text {th }}$ century, which were expressed in the establishment of different nation states with clear boundaries.

In addition, on the level of the organization, the Islamic State has a clear hierarchy in the processes of decision-making. Systemic decisions are made in a centralized manner by the leadership and senior member of the organization, while tactical decisions are made on the field levels and the local ranks. There is a severe compartmentalization between the ranks of the field and the ranks of the decision makers so that if in certain 
places the Islamic State is defeated, this will be at the local level and will not influence the intermediate and higher ranks. In the economic field, the Islamic State finds diverse sources of financing, such as: kidnapping and ransoming, weapons smuggling, taking over financial institutions in the places they conquer, and using natural resources such as taking over oil fields etc. (Perlov, 2015: 94).

However, it becomes clear that the Islamic State is a far greater phenomenon than the territorial basis and the state structure that was based on northeast Syria and northwest Iraq. The Islamic State has four dimensions. It is a country and it includes a collection of terrorist organizations loyal to it in many places in the world, such as the districts of Sinai and Libya. It is a global terrorist organization which attacked Paris and took down a Russian airplane in the Sinai Desert. Above all it is an extreme ideological religious idea that is spreading virally and virtually, with presence and influence on Internet websites and social networks (Yadlin, 2015: 240).

In addition, it is necessary to address a legitimate question. Why, despite the limited military abilities of the Islamic State, are the countries of the Middle East, the European Union, Russia, and the United States troubled and worried by it? Significantly, a part of the question is found largely in the nonmilitary parameters of the activity of the Islamic State: the messages in the religious and ideological facet, the communicational means through which the Islamic State disseminates its messages, and the psychological effect, including the creation of intimidation, which inspire the criminal and brutal deeds of the Islamic State against people and their property.

The additional part of the answer to the riddle of the Islamic State organization lies in the vicissitudes and governmental vacuum that followed the Arab Spring, which expressed the climax of the search after a new way in the Western world. In addition, the political-social-economic crisis steadily worsened. The public, especially the younger public, continued to search for a new way through in which it was possible to connect ideologically and socially. The jihadist Salafi Islam proposed a new-old idea of the Caliphate, which exists according to the laws of Sharia (Yadlin, 2015: 242).

The idea of the Caliphate is carried on the social network, which is accessible by masses of people around the world. In light of the power of its impact, it serves the Islamic State and answers a number of goals. The first and significant one is the recruitment of personnel (Zelin, 2013, in Perlov, 2015: 96). Beyond this goal, the network serves as a central platform for the increase of the processes of radicalization among the potential audience in the Arab and Western countries (Berger, Strathearn, 2013, in Perlov, 2015), and the raising of funds (Berger, 2014, in Shweitzer, Einav, 2015: 96).

Radicalization produces an atmosphere of fear at a minimal cost, and enables mobility of the mass forces. It also creates a brand with meaning and prestige, in visual terms, through the use of the effects of sound and picture. Additionally, it coordinates the movement of forces in the field, and grants 'eternal life' for ideas and ideology. Although in actuality the Islamic State fighters themselves are at increased risk and can die. The attempts undertaken over time, to deal with the phenomenon called the Islamic State online, led to the opposite result and caused it to grow stronger. Aside from the dissemination of messages and propaganda conveyed through these instruments, 
the fighters of the Islamic State can coordinate and document their actions through applications and production companies that the organization established.

In addition, the Islamic State has one of the broadest and most effective systems of propaganda in the Middle East, and a tourist project to bring foreign Muslim fighters and citizens to the areas under its control. It does this through a sophisticated constellation of marketing and public relations, which operates in more than 24 languages in the countries of: Europe, Africa, and Asia (Perlov, 2015: 97).

\section{EUROPE, THE THREAT, AND WAYS OF COPING}

Many researchers maintain that terrorist organizations find that the democracy that characterizes Europe and the West, to be a comfortable arena for action. On the one hand the democratic regime is characterized by values and governmental arrangements, that grant a variety of possibilities to the development of terrorist cells and establishment of terrorist organizations. On the other hand, the values of democracy limit structurally the abilities of the government in the country, to undertake actions that can reduce and cope in a good and successful way with terrorist organizations (Farrell, 1982: 119).

Wilkinson maintains that in the liberal democracy that characterizes the countries of Europe and the West the terrorist organizations are allowed to exploit the variety of freedoms that the democracies allow. This includes the dissemination of propaganda and messages intended to erode the values of democracy and its elected representatives, such as: freedom of speech, freedom of movement, and organization. These freedoms enable the terrorist organizations to establish themselves and grow stronger, unhindered, and even to move around the countries to perform terrorist attacks (Wilkinson, 1976: 11).

One of the challenges that should be addressed is the free and uncensored communication that characterizes democracies in Europe in particular, and in the West in general. The systems of communication that are very developed in the countries of the West and in Europe are not subordinate to the factors of the government, and thus, are not 'obligated' to given an accounting to the government. This includes censorship of the information it publishes. The terrorist organizations exploit the media's openness and convey through it their messages from the areas of the terrorist attacks and the results of the terrorist attacks, directly to the citizens who are attentive to the different means of communication (Janke, 1992: 213).

A good example is the Islamic State's use of the media to present to the world - live - the fighting, the horrific actions, and the executions.

The idea and the phenomenon of the Islamic State, and the culture that it adopted, and the ideology that surrounds it; create for Europe an inherent difficulty in the ability to advance in the efforts to solve the internal conflicts in countries such as: Syria, Iraq, and Lebanon. Europe attempts to reduce the situation of crisis, and to restore the situation to its preceding state, when the final outcome is to strengthen the old country order. The establishment of offshoots of the Islamic State in a number of Arab countries, including: Europe, Lebanon, and Jordan, countries that have shared interests 
with Europe, threatens to increase the lack of stability in them in particular and in the Middle East in general.

Dr. Abdallah Azam, who continues in the path of Osama Bin Laden, developed a perception. According to which, a holy war (jihad) against the heretics must become a parallel track, and sometimes-alternate track, to war against the heretical regimes that control the Islamic world. Jihad must be worldwide, and it is necessary to strike at the heretics who control areas that belong to Islam (such as Chechnya, the Balkans, etc.). In addition, it is necessary to hit at the economy of the West, which is the source of the resilience of the heretical regimes in the Islamic countries.

The vision of Abdallah Azam captivated people, primarily members of the second and third generation of immigrants from the Middle East and North Africa to Western Europe. These young people did not succeed in jumping the class hurdle of the members of the first generation who immigrated, and therefore the message of Abdallah Azam and Bin Laden was well-received, like "dew on dry soil" (Sivan, in Cohen, 2015: 6).

The threat of the Islamic State has extended beyond the borders of the Middle East. Already in the years 2014 and 2015 a series of terrorist attacks were performed by terrorists, who were sent by the Islamic State to the heart of Europe such as: Brussels, Paris, Copenhagen. The dominant one was the lethal terrorist attack in Paris on November 13, 2015. Then the countries of Europe understood the potential innate in such events and the danger of the increase of such events (Stein, 2015: 216). In the years 2016 and 2017, terrorist attacks were carried out by Islamic State. The last was the vehicle attack in the month of August 2017 on the Ramblas Boulevard in Barcelona Spain, a terrorist attack that took the lives of innocent citizens.

Part of the effort to cope with the threat that is presented by the Islamic State, including the effort in the military field to eliminate this phenomenon, is clear to the countries of Europe since to succeed in the struggle the mode of action must be combined and multi-system. The understanding of the way of action needs to be expressed in the arranged strategy, that includes all the areas in which it is necessary to act simultaneously; such as addressing the idea-ideology, the media, the economy and financial resources, and resolute operative activity against the terrorist attacks. The outcome of these actions is the hermetic sealing, to the greatest extent possible, of the resources so that the Islamic State cannot exploit them for its goals (Stein, 2015: 216).

The countries of Europe are required to crystallize together on the one hand a strategy and on the other hand operational synergy, which will provide an effective solution for another topic, no less important than the threat of terrorist attack from the outside, and it is the threat that is growing stronger from Europe itself. This threat comes from the residents of Europe who joined the ranks of the Islamic State and acquired combat operational experience. They then returned to their countries of origin, and constitute a potential reservoir for terrorist cells; bearing the idea of the Islamic State and the desire to instill it through murderous terrorist attacks in the heart of Europe (Stein, 2015: 217). In addition, there are citizens with a Muslim origin who were 'conquered' in terms of awareness and ideology by the ideas of the Islamic State. These people are interested in participating in the terrorist attacks as a part of their contribution to the ideology and the war, against the heretics and the crusaders represented by Europe. 
The countries of Europe where there are large concentrations of a Muslim population constitute a source for the recruitment of young people, to the ranks of the idea of the Islamic State. The countries of Europe lag significantly behind in the preparations to cope with the problem. The dominant countries are primarily Germany, Belgium, Austria, Denmark, and Sweden. In contrast, France and Britain, which have experienced terrorist attacks, began to draw conclusions. In light of these conclusions and the recognition that the threat is internal to Europe, these countries began to prepare better for the future. The former Prime Minister of Britain, David Cameron, emphasized in a speech he gave in the British Parliament after the terrorist attack in Tunisia, the importance of coping with the incitement and radical influence of the Islamic State. This poisons, in his words, the minds of young people. He even compared between the challenge set by jihadist Salafi Islam and the challenge of Communism in the years of the Cold War (Cameron, in Stein, 2015: 217).

The main reason for the increase of the Muslim population in Europe is the birthrate among the Muslim immigrants, which is far higher than the low birthrates of the local population, which may even be characterized by negative growth. Some estimate that the birthrate of the Muslim population in Europe is three times that of the Western European population. In Britain, for illustrative purposes, the increase in the percentage of the Muslim population was tenfold in the years 2004-2008, when the number of the Christian residents in the country declined by about two million people. Consequently, there were sociodemographic changes throughout Europe. Estimates today are that there are about twenty million Muslims in Europe. Withinn a decade the number will reach thirty million people (fifty million including the illegal immigrants) (Nachmani, 2007).

The countries of Europe must act resolutely, and even allocate many resources against the threat they face, on the part of the Islamic State in the west. It is possible to note that the dimensions of the Islamic State in Syria and Iraq are steadily being reduced in terms of territory, although in terms of ideology and awareness there is no decline in the motivation and willingness on the part of its members in Europe to execute terrorist attacks. General and 'unsophisticated', easily executed terrorist attacks in particular, such as running over innocent people on sidewalks and killing dozens of innocent civilians in the name of the murderous ideology.

It will be emphasized that the crisis in Syria and in Iraq lasted primarily in the humanitarian dimension, which is worsening, and in the steadily increasing flow of refugees and asylum seekers who came and continue to come to Europe. Europe is not prepared to absorb them and to deal with the phenomenon capably and in the short term, and not even in the long term. In addition, the countries of Europe have yet to delineate a clear policy line that will provide a response to this challenge. A most illustrative example of the powerlessness of the countries of Europe in their handling of the problem of refugees is expressed through the agreement of the European Union to transfer about 40,000 refugees to a number of countries, when the main ones are Germany, Sweden, France, Italy, Greece, and Hungary (Norrington, 2015, in Stein, 2015: 218).

Another challenge that the democratic governments in the West face is the limitations of punishment, which constitute a foundation stone in a democratic regime. The 
democratic governments cannot act using all the effective means, since some are not found in the framework of the country's laws. Moreover, the governments themselves are subject to these laws that impose limits. Clawson holds that the enforcement of the law in the democratic governments will be effective when it will be through consensus. Or in other words, the agreement of both the government and the citizens who belong to the state in all that pertain to the allotment of resources and the performance of operative actions against threats (Clawson, 1990: 28).

Another significant question is the question of the preservation of human life in the country and the 'price' that the governments of the West need to pay as part of the war on terrorism. Since the terrorist organizations that always search for the soft spot can take a higher price from a country that sanctifies values of freedom and democracy, than from a country that does not act democratically and that does not value human life (Danforth, 1980: 117). In addition, it is necessary to take into account that democratic countries are more exposed to harm because of the openness and pluralism that characterize them (Guiffrida, in Alexander, Denton, 1986: 24).

The countries of Europe in particular and the West in general are found in a situation of value-oriented conflict between the strong desire to fight terrorism through the use of violent means, and emergency legislation. This includes punishment for the purpose of deterrence, which may reduce the threat and even the acts of terrorism. In contrast, the democratic liberal values that characterize the democratic countries, a conflict that can lead to international criticism in light of the use of undemocratic steps (Crenshaw, in Reich, 1998: 14-15).

It should be noted that the avoidance of the adoption of steps that will ensure the wellbeing and safety of the citizens, through the preservation of the values of democracy, may cause an escalation in the acts of terrorism against the innocent citizens. This will cause the erosion of the legitimacy of the elected government. An elected government must uphold the personal and physical safety of the citizens of the country over which it has charge. There are cases in which the values of democracy and the preservation of human life clash, and in some cases contradict (Wilkinson, 1986: 17).

Wilkinson maintains that the conflict how to behave is prominent primarily after the occurrence of a terrorist event that takes many victims. When the citizens of a State call upon the government to act with resolution against terrorism, including the harm to freedoms, so as to cope effectively with terrorism (Wilkinson, 1988: 42).

Bandura posits a similar assertion: the tendency of the government is to adopt extreme and undemocratic steps when the terrorism becomes more than an annoyance, when the functioning of the state and society is not possible, thus causing pressure on the government to fight terrorism and to defeat it by all possible means (Bandura, 1998: 167)

In light of the aforementioned statements, the following question is asked. What can be done to reduce the exposure to acts of terrorism, and to increase the effectiveness in fighting these actions? Schmid and Crelinsten hold that the democratic governments need to make a significant decision. Whether to harm the democratic order so as to be effective in the war against terror, or whether the democratic governments need to take into account an acceptance of the terrorist events with the attempt to reduce them without harming the democratic order at all despite the terrorist attacks (Schmid, Crelinsten, 1993: 15). 
In addition, other researchers maintain and propose that it is possible to fight against terrorism with the minimal harm to the democratic order. One of the examples is the argument of Robert Moss. According to Moss: when fighting terrorism in the crowded cities it is necessary to display a fair amount of tolerance, since the security forces when performing the activity to identify the terrorists can inadvertently harm innocent citizens. Therefore it is necessary to reduce as much as possible the number of people defined as terrorists, so as not to cause the opposite effect in which the citizens display lack of tolerance and lack of understanding of the activity of the security forces. Furthermore, it is necessary to allow the citizens who are harmed by the activity of the security forces to criticize the governments' activity, as long as the criticism is within the framework of legitimate criticism (Moss, 1976: 46).

Charters asserts that in a historical look it is possible to learn that there are successes in the war against terrorism, without harming the democratic order and values that accompany this order. He even notes Italy, France, and Germany, as examples of countries that have succeeded in reducing in general the potential and the degree of harm without trampling the principles of democracy (Charters, 1991: 348).

\section{$* * *$}

The radical global terrorism that strikes all around the world, which realizes the argument that World War III is already here, is a product of the clash of civilizations. To confirm these statements it is enough to address the threat posed by the Islamic State in the intra-European arena, but it is possible to go further. Like with a variety of other internal threats on the part of extremists from the left and from the right, the main dilemma with which democratic societies cope in the struggle against terror arises. At the center of this dilemma there is the need to find a balance between, on the one hand, the freedoms of the individual and on the other hand, the means to be adopted to reduce the threats it faces, which entail the limitation of the individual freedoms.

The differences between the civilizations are profound and deeper than the differences between the different ideologies. Every civilization has a different outlook on issues and fundamental concepts, such as the relations between men and women (for instance in the family), the relation between rights and duties, between freedom and authority, and between equality and hierarchy. For the most part the fundamental difference and the gaping chasm between the terrorist organizations, with the countries that support them, and the West cannot be bridged. Thus the idea of the Islamic State attempts to sweep through Europe, with the desire to make Europe into a part of the idea of the Caliphate, if not physically at least in awareness.

Western power has no competitors, at least in the foreseeable future, and it maintains its supremacy relative to other civilizations in all the dimensions. The West has absolute control in the international political, security, and economic institutions, and consequently can manage the world in a way that preserves the Western hegemony. This protects Western interests and promotes Western values in the policy and economy.

It is important to understand this principle position also in the public internal context, in the Western countries in general, and in Europe in particular. Although, many 
object in principle to the deployment of soldiers to the combat zones outside of Europe. It is possible that the change in this approach may occur only in the case of the occurrence of terrorist attacks with multiple casualties, at a high frequency that will cause a change in the approach. For example, an event that it will be possible to attribute directly to the Islamic State, or if the risk increases that the Islamic State will threaten in a tangible manner the political and economic interests of the countries of Europe.

The international system against terrorism of Al Qaida and its partners succeeded in preventing most of the terrorist attempts, until the rise of the Islamic State that today is at the head of the global jihadist 'camp'. The Islamic State is a terrorist entity that controls territory, at the disposal of which there are economic means and greater manpower than at the disposal of Al Qaeda and its partners. However, the experience and the knowledge accumulated in the fighting against global jihadists led by Al Qaeda can facilitate the coping with the challenge that the Islamic State poses, through the adjustment of the action strategy against it, with its methods and the conditions under which it acts.

The recent terrorist attacks that occurred in Europe were carried out under the guidance of the Islamic State, through its international unit for terrorist attacks. This unit deployed members of its network who were trained and prepared by it to conduct terrorist attacks for it and in its name in Europe. Thus, the Islamic State proved, if there were still any doubts, that there is a large pool of Western volunteers who had invaded Syria in recent years. Intended not only to serve as cannon fodder that produces suicide bombers in Iraq and Syria, or spreads propaganda, but trained by design to execute terrorist attacks in the West according to the need and the possibilities. This was a part of its international campaign strategy. Since there are several thousands of Western volunteers, in numbers ranging according to different estimates from five thousand to seven thousand, it is possible to assume that from all these more than a few will volunteer to carry out a terrorist attack and some will succeed in their scheme (Schwitzer, Eran, 2016: 1).

The West and Europe together are in this struggle, which necessitates: closer supervision over the institutions of religion in Europe, closer follow up after the different charity organizations, and the strengthening of security systems in the different public service facilities, such as aviation and transportation services. The cumulative impact of the reports of the brutality of the Islamic State, the destruction and the ruin it causes, and the terrorist attacks in major European cities; increase the willingness of the public in Europe to accept the harm, even partially, to the principles that until now have been sacred.

The leadership in the West in general and in Europe in particular must declare and convince the Muslim population and its leaders who live in Europe, and who want to live in peace and integrate into the European system, that the war against terrorism is not a war against Islam. In a positive and participative approach, the Muslim majority in Europe may constitute a part of the campaign against the jihadist Salafi terror, and it is necessary to make certain that it does not become a part of the problem.

With the integration of forces and resources the West can win the battle against murderous radical entities, that are motivated by the unbridled Messianic ideology that 
tramples in every possible way the basic values of humaneness. Some will say that the phenomenon of the Islamic State is the problematic answer to the question of what happens when a radical Messianic ideology relevant to the seventh century, meets the forefront of technology of the twenty-first century - chaos.

\section{REFERENCES}

Alexander Y., Denton J. (eds.) (1986), Governmental Responses to Terrorism, Hero Books.

Bandura A. (1998), Mechanisms of Moral Disengagement, in: Origins of Terrorism, (ed.) W. Reich, Woodrow Wilson Center Press.

Charters D. A. (1991), Counterterrorism Intelligence: Sources, Methods, Process, and Problems, Democratic Responses to International Terrorism, Transnational Publishers Inc., New York.

Clawson P. (1990), US Options for Combating Terrorism, in: The Politics of Counter Terrorism, (ed.) B. Rubin, John Hopkins Foreign Policy Institute.

Cohen D. (2015), Between Imagined Reality and Real Terrorism, "Military and Strategy", 7 (3), December (Hebrew).

Crenshaw M. (1998), The Logic of Terrorism: Terrorist Behavior as a Product of Strategic Choice, in: Origins of Terrorism, (ed.) W. Reich, Woodrow Wilson Center Press.

Danforth J. (1980), Terrorism and Democracy, "International Terrorism", The Jonathan Institute, Jerusalem.

David Cameron Speech in Birmingham (2015), “The Independent”, July 20.

Farrell W. R. (1982), The U.S Government Response to Terrorism: In Search of an Effective Strategy, Westview Press, Colorado.

Harkavi Yehoshaphat (1983), On Guerilla Warfare, "Systems", Tel Aviv (Hebrew).

Huntington S. P. (1993), The Clash of Civilizations?, "Foreign Affairs”, Summer, 72 (3).

Janke P. (1992), Terrorism and Democracy, Some Contemporary Cases, Macmillan, London.

Lewis B. (1990), The Roots of Muslim Rage, "The Atlantic Monthly”, September, 266 (3).

Moss R. (1976), Urban Terrorism: Political Violence in Society, "Cyclone", 1 (Hebrew).

Nachmani A. (2007), On the Verge of an Open Clash? On Muslim Immigration to Europe, in: The Importance of Being European: Turkey, the EU \& the Middle East, (eds.) N. Goren, A. Nachmani, The Hebrew University of Jerusalem - European Forum at the Hebrew University, Jerusalem.

Netanyahu B. (1996), Fighting Terrorism: How the Democratic Regimes Can Defeat Domestic and International Terrorists, Yediot Acharonot, Sifrei Hemed, Israel (Hebrew).

Perlov O. (2015), Guide to the Galaxy of the Islamic State, in: The Islamic State: A Black Flag Flies over It, (eds.) Y. Shweitzer, O. Einav, The Institute for National Security Studies, Tel Aviv (Hebrew).

Schmid A. P., Crelinsten R. D. (eds.) (1993), Terrorism and Political Violence, Frank Class, London.

Schultz G. P. (1997), The Challenge for the Countries of Democracy, in: Terrorism: How the West Can Win, (ed.) B. Netanyahu, Sifriat Maariv (Hebrew).

Shweitzer Y., Eran O. (2016), Coping with Terrorism without Falling into Its Trap, "A Look from Above", 808, The Institute for National Security Studies, Tel Aviv, March 24 (Hebrew).

Sivan E. (2015), Conflict in Islam, in: The Battle of the 21 $1^{\text {st }}$ Century: Democracy Fighting Terrorism, (ed.) H. Pas, Jerusalem, The Israeli Institute of Democracy, Jerusalem. 
Stein S. (2015), The European Union and the Rise of the Islamic State, in: The Islamic State: A Black Flag Flies over It, (eds.) Y. Shweitzer, O. Einav, The Institute for National Security Studies, Tel Aviv (Hebrew).

Wilkinson P. (1976), Terrorism versus Democracy: Anatomy of Conflict, "Cyclone", 1 (Hebrew).

Wilkinson P. (1986), Terrorism versus Liberal Democracy: The Problems of Response, "Contemporary Terrorism", Facts on File Publications, New York.

Wilkinson P. (1988), British Policy on Terrorism: An Assessment, "The Threat of Terrorism", Wheatsheaf Books, Great Britain.

Yadlin A. (2015), The Challenges of the Islamic State - Is This Really the Case?, in: The Islamic State: A Black Flag Flies over It, (eds.) Y. Shweitzer, O. Einav, The Institute for National Security Studies, Tel Aviv (Hebrew).

\begin{abstract}
The struggle against global terrorism is taking place, and it is between civilizations. It is a war against radical international terror, which is attempting to change the world order and is sowing fear among both citizens and governments. Huntington maintains that people can re-define their identity and consequently the boundaries and compositions of civilizations change. The phenomenon of the 'Islamic State' illustrates this. There is a cultural difference between civilizations that support Islamic terror, which tramples individual rights, and Western civilizations that are dedicated to pluralism and democracy. The Western world for already seven decades has been under attack by international terrorism, and the peak is the phenomenon of the 'Islamic State', which began in the Middle East and now is attacking Europe, and not just Europe. A difficult global war is being waged, and it is necessary to find an effective response to the threat. This response will include a multi-system strategy that addresses ideology, media, financing, and operational activity, including the handling of European residents who joined the ranks of the Islamic State and acquired operational experience, returned to Europe, and constitute an infrastructure of terrorism and terrorist attacks. The integration of forces and resources, significant operational activity, and legislative changes that curtail individual liberties, in cooperation with the moderate Muslim population, will enable the West and Europe to defeat the terrorist entities that trample in all ways the fundamental values of humanity and human life.
\end{abstract}

Keywords: Global terrorism, fighting terrorism, Islamic State, national security, democracy, media

\title{
WOJNA Z TERRORYZMEM JAKO ZDERZENIE CYWILIZACJI
}

\section{STRESZCZENIE}

Poniższy artykuł zasadza się na hipotezie, iż trzecia wojna światowa jest realną możliwością i prawdopodobnie będzie ona wojną pomiędzy cywilizacjami. Wojna ta, jest wojną z radykalnym międzynarodowym terroryzmem, którego celem jest zmiana porządku w świecie oraz zaszczepienie strachu w obywatelach i rządach państw. S. Huntington zakłada, iż ludzie są w stanie redefiniować swoją identyfikację kulturową, podobnie jak zasady oraz granice własnych cywilizacji. Fenomen tak zwanego Państwa Islamskiego jest szczególnym przykładem takiej zależności. Istnieje kulturowa różnica pomiędzy cywilizacjami wspierającymi islamski 
terroryzm (które odrzucają prawa jednostek) oraz cywilizacją Zachodu, które wyznają zasady pluralizmu i demokracji. Świat Zachodu od ponad siedmiu dekad jest nieustannie nękany przez międzynarodowy terroryzm, którego szczytem jest fenomen tak zwanego Państwa Islamskiego, które powstając na Bliskim Wschodzie zagraża Europie i nie tylko jej. Trudna światowa wojna, która nadchodzi musi być efektywną odpowiedzią na to zagrożenie. Odpowiedź ta wymaga multi-systemowej strategii, która uderza w ideologię, media, finansowanie, działalność operacyjną (włączając w to identyfikowanie obywateli europejskich, którzy dołączyli do ISIS i zdobyli doświadczenie bojowe i konstruują nowe siatki terrorystyczne na miejscu). Integracja sił i środków, aktywność operacyjna oraz zmiany prawne redukujące wolności osobiste we współpracy z umiarkowanymi muzułmanami, pomogą Zachodowi i Europie pokonać terroryzm, który zagraża fundamentalnym wartościom ludzkości i życia ludzkiego.

Słowa kluczowe: globalny terroryzm, walka z terroryzmem, Państwo Islamskie, bezpieczeństwo narodowe, demokracja, media 
